\title{
Transnational Islam, Regional Terrorism, and Military Power: The Rise of Muslim Special Unit in the Philippines Armed Force
}

\author{
Bayu Mitra A. Kusuma, Sunan Kalijaga State Islamic University, Yogyakarta, \\ Indonesia
}

\begin{abstract}
The Southern Philippines is known as one of the areas that never gets out of conflict. Even so, in 2017, the public was shocked by the emergence of the Maute group in Marawi which is affiliated with ISIS, also known as Daesh, who are transnational terrorists. They commit many human rights violations such as kidnapping and murder. In addition, terrorist groups that have existed before, like Abu Sayyaf, often operated by crossing several Southeast Asian countries' water boundaries, so the problem is transformed into a regional issue. This study aims to describe and analyze the relationship between transnational Islamic movements, which are the cause of regional terrorism, and the opposition formed by an alternative military approach in combination with religion. These approaches were formed after conventional military actions were felt to be too difficult. This research's results show that, to face the difficulties of conventional military approaches, the Philippines government formed a Muslim special unit in their military force. On the one hand, this change could have positive impacts. Religious and cultural approach, compared to a conventional military approach, can open up a larger dialogue space. Therefore this unit can be more adaptable because it has the ability to gain local community support. Finally, this specialized unit can facilitate military coordination and cooperation with Indonesia, Malaysia, and Brunei Darussalam as they are allcountries with a majority Muslim population. But, on the other hand, this specialized unit can also have negative impacts. For example, there is the potential emergence of factions within the military or gap between the Muslim units with other soldiers. Also, this unit can reinforce the stigma that Muslims are terrorists and must be fought with hard-core Muslims that are in military uniform.
\end{abstract}

Keywords: Transnational Islam, Regional Terrorism, Muslim Special Unit, the Philippines Military

\section{INTRODUCTION}

Nowadays, various forms of terrorist attacks are increasingly dangerous, and they spread throughout the world. These attacks are not only in the Middle East, but they also extend to Southeast Asia which is now facing frontal attacks. In historical context, the threat of extremism and radicalism that led to the acts of terror began to receive a big response from ASEAN after the September 11, 2001 tragedy on 
Transnational Islam, Regional Terrorism, and Military Power: The Rise of Muslim Special Unit in the Philippines Armed Force

the World Trade Center in the United States and the Bali Blast on October 12, 2002 in Indonesia. ${ }^{1}$ The topic of terrorism is both complex and emotive. The topic is complex because it combines many different aspects of the human experience, including subjects such as politics, psychology, philosophy, military strategy, and history. ${ }^{2}$ In Southeast Asia, the fundamental problem of terrorism cannot be separated from the majority-minority relationships and heterogeneity. Not much different from the conditions of minority groups in other parts of the world, the part of the southern Philippines that is the basis for Muslim society is also a conflict-prone area in regard to religious and ethnicity backgrounds. Muslim minorities in the Philippines are popularly referred to as Moros. The term has a pejorative connotation and symbolizes the general disease of the Muslim position in relation to the majority people. ${ }^{3}$ The bad connotation makes Muslims in the Philippines feel discriminated socially and culturally.

In the Philippines, Muslims initially prefered peaceful ways to gain sovereignty or freedom in organizing their lives. However, they began to think that the constitutional struggle for independence could not be done peacefully under the conditions of the period. This is because, humans have two potentials in their self, namely love for their identity group and aggression, as proposed by Ibn Khaldun in Muqaddimah. ${ }^{4}$ Therefore, led by Nur Misuari, Muslim group in the Southern Philippines formed the Moro National Liberation Front (MNLF) to organize their struggle through an armed way. But then this intention changed when the Philippine government started negotiations with MNLF in 1975. MNLF began to soften, willing to negotiate and compromise, until finally one year later they reached an agreement on the framework of conflict resolution in the Southern Philippines.

This agreement is known as the Tripoli Agreement. It was signed on 23 December 1976 in Tripoli, the capital city of Libya, between MNLF and the Philippine government. The main point of the Tripoli Agreement was for the MNLF to receive autonomous status in the southern Philippines regions covering thirteen provinces: Sulu, Basilan, Tawi-Tawi, Zamboanga del Sur, Zamboanga del Norte, North Cotabato, Manguindanao, Sultan Kudarat, Lanao Norte, Lanao Sur, Davao Sur, South Cotabato, and Palawan. ${ }^{5}$ Under the agreement full autonomy in the field of courts and education was given, while the field of defense and foreign

1 Ralf Emmers, "ASEAN and the Securitization of Transnational Crime in Southeast Asia", The Pacific Review Vol. 16 No. 3, (2003).

2 United States Institute of Peace, "Teaching Guide on International Terrorism: Definitions, Causes, and Responses", Education Program Vol. 202, (2001), p. 3.

3 Peter G. Gowing, "Moros and Khaek: The Position of Muslim Minorities in the Philippines and Thailand", in Reading on Islam in Southeast Asia, ed. Ahmad Ibrahim et al. (Singapore: Institute of Southeast Asian Studies - ISEAS, 1985), p. 184.

4 Hakimul Ikhwan Affandi, Akar Konflik Sepanjang Zaman: Elaborasi Pemikiran Ibn Khaldun, (Yogyakarta: Pustaka Pelajar, 2004), p. 84.

5 Christine Bell and Vanessa Utley, "Chronology of Mindanao Peace Agreements", The Political Settlements Research Programme Briefing Paper Vol. 2, (2015), p. 1. 
policy remained under the authority of the central government in Manila, the capital city of the Phillipenes. On the other hand, the Tripoli Agreement sparked a split within the MNLF. There was a faction that accepted the terms of the Tripoli Agreement and a faction that rejected the agreement. Those who rejected the Tripoli Agreement broke away and formed a new group called the Moro Islamic Liberation Front (MILF), while the more extreme factions later formed the Abu Sayyaf group. It should be noted that the MILF and Abu Sayyaf are currently two hostile groups due to differences in understanding, approach, and methods.

After the Tripoli Agreement was signed, the social life of the communities in the thirteen provinces of the predominantly Muslim, southern Philippines improved. But these peaceful conditions did not last long because the continuation of the peace agreement signed in Tripoli was finally betrayed by President Ferdinand Marcos himself by holding a referendum in the thirteen provinces contained in the Tripoli Agreement. The argument used by Marcos was to find out whether the population of the thirteen provinces was to be granted the special autonomy in the agreement or not. But, the intention of Marcos's referendum was nothing more than a trick to break the Tripoli Agreement smoothly. Because, before the referendum was done, Manila first moved a massive amount of people in the largely Catholic majority of the North Philippines.

Due to this migration, the southern region, which used to be comprised of a Muslim majority became predominantly Catholic. This condition was intentionally done in order to ensure that the results of the referendum would be what was expected by Marcos: that the majority of the people would reject the special autonomy because the newly moved population also directly had the right to vote. ${ }^{6}$ As a result, the Muslim community fought against the result of the referendum which they believe to be full of fraud, so that religious social conflicts raged again, which still lasts today. To make matters worse, the Muslim community was labeled a terrorist group. Runningthe resistance certainly needed a lot of money. These conditions forced the militias to look for alternatives in finding funds. For the Abu Sayyaf group, one of the avenues they often chose was the abduction of foreign people to demand large compensation. This compensation would come from private companies or the government of the abductees' country of origin.

Since the end of 2015, the news regarding piracy and kidnapping in the Indonesian-Philippine border waters was endless. Kidnapping happened again shortly after a meeting which resulted in the Memorandum of Understanding $(\mathrm{MoU})$ between the armed forces chiefs of Indonesia, Malaysia, and the

6 Bayu Mitra A. Kusuma, "Islam, Asymmetric Policy, and Social Conflicts: The State's Role as a Root of Radicalism in the Philippines and Thailand", IKAT: The Indonesian Journal of Southeast Asian Studies Vol. 1 No. 1, (2017). 
Transnational Islam, Regional Terrorism, and Military Power: The Rise of Muslim Special Unit in the Philippines Armed Force

Philippines in the middle of 2016. It should be noted that the commander of the three armed forces signed an agreement on May 5, 2016 that contains four points. First, the three countries agreed to jointly patrol the border waters. Secondly, they agreed to provide assistance as soon as possible if there are people or boats in trouble and in need of help. Third, the agreement established a national focal point among the three countries to facilitate the sharing of information and intelligence in a short time. Finally, hotline communication was created between the three countries to accelerate response time in the case of emergency situations.

The high intensity of abductions seems to illustrate that as de facto the water area has been controlled by militias or armed groups, in this case, the Abu Sayyaf group. Abu Sayyaf is not an amateur militia. They are highly trained, modernly armed, and a loyal follower of Abu Bakar Al-Baghdadi, the supreme leader of the Islamic State of Iraq and Syria (ISIS), or Daesh, who was recently reported to have been killed. It should always be emphasized that global and regional outlook is bleaker. Consider the challenge of the international network of terrorism. Experience indicates that terrorist groups thrive on collaboration across national boundaries. ${ }^{7}$ Kidnapping is aimed at large compensation from the hostage's state government. This money is strongly suspected to be used as a financing source for terrorist activities which, according to their distorted perspective, is "jihad. ${ }^{8}$ In 2015 alone, the number of Filipinos recruited by ISIS is around 200 people. $^{9}$ If this recruitment continues to be left, then ISIS recruitment will become greater. ISIS has made the southern Philippines their base in Southeast Asia and appointed Isnilon Hapilon, also known as Abu Abdullah al-Filipini, as the ISIS leader for Southeast Asia. ${ }^{10}$

In addition to the two free deliveries without compensation of Indonesian citizens in 2016, generally the victim release by Abu Sayyaf militia ends with a compensation payment. For example, an Italian citizen was released after being redeemed for millions of pesos. This is in contrast to the tragic fate of the Canadian hostages who were executed after the requested compensation for the militia was not paid by the deadline that was determined. If there is a conversation concerning risk management, all the mechanisms of hostage release must be considered a risk. The military option is actually very dangerous considering the Abu Sayyaf militia is controls the terrain, understands secret shortcuts in the forest for guerrilla, and is supported by some surrounding communities. Therefore, the military operation has the potential to give birth to an asymmetrical war that will

7 Yonah Alexander, "Contemporary Terrorism: From National to Regional and Global Threats", Defence Against Terrorism Review Vol. 1 No. 2, (2008), p. 42.

8 Bayu Mitra A. Kusuma, Abu Sayyaf Piracy: An ASEAN Political Security Challenge, online: http://isais.or.id/en/abu-sayyaf-piracy-an-asean-political-security-challenge, (July 4, 2017).

9 Ahmed S. Hashim, The Impact of the Islamic State in Asia: Policy Report, (Singapore: S. Rajaratnam School of International Studies - RSIS NTU, 2015).

10 Sidney Jones, "Pro-ISIS Groups in Mindanao and Their Links to Indonesia and Malaysia", Institute for Policy Analysis of Conflict (IPAC) Report Vol. 33, (2016). 
greatly benefit the militia. The fact that these kidnapping cases affect foreign nationals, the kidnapping locations are within the border areas of the country, and that complex handling must be done by several countries, all make Abu Sayyaf kidnapping a regional terrorism issue.

Furthermore, this in-depth study will sequentially explain the relationship between the threat of the transnational Islamic movement, which is the cause of the emergence of regional terrorism, and the opposing military power. But, because conventional military power has not produced results, the Philippine government tried an alternative approach by combining military and religion in the formation of the special Muslim units within their military bodies.

\section{STATE BORDER AREAS AND REGIONAL TERRORISM}

Borders are the outermost frontier and often the most remote areas. Because of their remote positions, the border areas often receive less attention from the government. But, on the other hand, borders are also regions that often lead to conflict between countries. For the example, the South China Sea case is very attention-grabbing. It is common knowledge that the People's Republic of China claims most of the South China Sea with their "nine dash line;" consequently, there is an overlap of claims with some other countries. They claimed the nine dash line as their traditional fishing area that has been going on for thousands of years. ${ }^{11}$ This claim is groundless given that the terminology is not recognized in the international law of the United Nations Convention on the Law of the Sea or UNCLOS 1982. ${ }^{12}$ The conflict of water border claims occur between China and many other countries, including Vietnam, Japan, Malaysia, and the Philippines. In this claim, the Philippines calls the South China Sea, the Western Philippine Sea. ${ }^{13}$

This conflict, which results from mutual claims, is so intricate and makes the constellation of relationships between countries unstable. This conflict is becoming an increasingly contentious source of geopolitical tension. ${ }^{14}$ It is because, originally, borders were used to delimit the territorial possessions of sovereign states, and the work of social scientists served the purpose of rulers who were

11 Agus Rustandi, The Impact of China's 'Nine-Dash Line' Claim on ASEAN's Role in the IndoPacific Region, (Canberra: The Centre for Defence and Strategic Studies (CDSS) Australian Defence College, 2015), p. 3.

12 Bayu Mitra A. Kusuma, "Mengelola Perbatasan dengan Border Governance", Jawa Pos Radar Banyuwangi, (Saturday, April 16, 2016), p. 38.

13 Aileen Baviera and Jay Batongbacal, The West Philippine Sea: The Territorial and Maritime Jurisdiction Disputes from a Filipino Perspective, (Manila: The Asian Center and Institute for Maritime Affairs and Law of the Sea University of the Philippines, 2013), p. 1.

14 Bert Chapman, "China's Nine-Dashed Map: Continuing Maritime Source of Geopolitical Tension”, Geopolitics, History, and International Relations Vol. 8 No. 1, (2016), p. 146. 
Transnational Islam, Regional Terrorism, and Military Power: The Rise of Muslim Special Unit in the Philippines Armed Force

eager to picture the boundary line demarcating their possessions. ${ }^{15}$ Another opinion states that national interests regarding the borders of countries are enormous because the border region affects the security, integrity, and sovereignty of a state. ${ }^{16}$ Such definitions are commonly used because most current political, geographical papers wish to understand the relationships between territory, sovereignty, and identity. ${ }^{17}$

In the internal conflicts of Southeast Asian nations themselves, it is undeniable that in the border areas between Indonesia, Malaysia, and the Philippines there are various water security challenges that must be faced by the three countries' authorities. Therefore, the threat of maritime piracy, hostage-taking, and transnational crime must be resolved as soon as possible. If this unsafe situation is not addressed quickly, it will impact the decline in the level of international confidence in the Southeast Asia region in general. This will impact trade, commerce, investment, and tourism. It must be admitted that not many are aware of the importance of the Sulu Sea and Sulawesi as strategic global economic waterways.

With the demise of the Cold War, new concepts of security that addressed not only the military realities of the contemporary world but also the political, economic, and social realities were developed. ${ }^{18}$ This is similiar with the piracy that occurred on the water border of Indonesia and the Philippines. The kidnapping is not only related to the Abu Sayyaf efforts to show their existence politically, but it is also strongly related to the economic gap and the vulnerability of social conditions of Muslim society in the southern Philippines. The threat of piracy is subsequently transformed into regional terrorism. Terrorism is defined as the recurrent or threatened use of politically motivated and clandestinely organized violence by a group whose aim is to influence a psychological target in order to make it behave in a way which the group desires. Terrorism constitutes the illegitimate use of force to achieve a political objective when innocent people are targeted. ${ }^{19}$ In the sense of regional terrorism, terrorism activities are carried out across borders in one region, such as the activity of Abu Sayyaf piracy in Southeast Asian countries water border.

Piracy that occurred in these territorial waters has already happened long enough. Beginning in March 2005, the Bonggaya 91 vessel was hijacked by the

15 Emmanuel Brunet-Jailly, "The State of Borders and Borderlands Studies 2009: A Historical View and a View from the Journal of Borderlands Studies", Eurasia Border Review Vol. 1 No. 1, (2009), p. 3.

16 Yohannes Sanak, Human Security dan Politik Perbatasan, (Yogyakarta: PolGov UGM, 2014), p. 15.

17 Henk van Houtum, "The Geopolitics of Borders and Boundaries", Geopolitics Vol. 10, (2005), p. 673.

18 Craig A. Snyder, Contemporary Security and Strategy, (New York: Palgrave Macmillan, 2008), p. 1.

19 Walter Laqueur, The New Terrorism: Fanaticism and the Arms of Mass Destruction, (New York: Oxford University Press, 1999). 
Abu Sayyaf group. Three crew members were taken hostage. Two hostages were freed by the Philippine military, but one was successfully taken into the forest by kidnappers. The hostage was only released six months later. The question arises of how the Abu Sayyaf group seemed so understanding of the movement of ships in the area. It seems that the destination point of the Abu Sayyaf group is always precise. There are allegations that the Abu Sayyaf has spread spies in various strategic positions. ${ }^{20}$ The alleged Abu Sayyaf spy was first made by Indonesian Armed Force (TNI) Commander at the end of 2016. The year in which the numbers of Indonesian flagged ships hiked sharply. There is the possibility that the Abu Sayyaf group commits piracy crimes easily because it gets information about the sailing of the ships from their espionage in Indonesia. Intelligence circles in Indonesia sniff out spys from the Abu Sayyaf network by placing military spy at strategic ports of Kalimantan Island.

When in the territorial waters of Indonesia or Malaysia, ships can still pass freely. However once entering Philippine waters, the existence of these ships becomes unsafe and piracy can happen anytime. The big question now is, why does piracy in the region seem so free. This puts the existence of the Philippine military into question. Does the Abu Sayyaf have an understading of the Patrol military patterns of the Philippines? Is the intensity of patrols by the Philippine military in their border waters so loose? Or, is the strength and fleet of the Philippine military not sufficient enough to maintain their entire territory, particularly border water territory? Therefore, before we discuss the emergence of Muslim special units in more detail, it is important to understand the posture of the Philippines military first.

\section{THE PHILIPPINES MILITARY: IDEAL PLAN VS CURRENT REALITY}

The military power development in Southeast Asian countries continues to show an increasing trend in the post-Cold War period. All countries in the region have engaged in forced modernization programs to varying degrees, although this does not equate with military effectiveness. While the Revolution in Military Affairs (RMA) has had varying effects on the region's military capabilities, it is important to note that much more than the mere acquisition of modern weapons systems is required for a true RMA to take place. ${ }^{21}$

Comprehensive military strength is not only based on how sophisticated the weaponry is but includes all aspects of the state apparatus and resources contained in a country that can be functioned immediately for war purposes. These include

20 Irwan Nugroho, Investigasi: Menelusuri Mata-Mata Abu Sayyaf, online: https://x.detik.com/detail/investigasi/20161013/Menelusuri-Mata- mata-Abu-Sayyaf/index.php, (July 13, 2017).

21 Andrew Tan, Force Modernisation Trends in Southeast Asia, (Singapore: Institute of Defence and Strategic Studies - IDSS NTU, 2004), p. 1. 
Transnational Islam, Regional Terrorism, and Military Power: The Rise of Muslim Special Unit in the Philippines Armed Force

the number of personnel, the major weapons systems, the power of maritime, logistics, natural resources, geographic strength, finance, and the supporting infrastructure. These eight aspects are subsequently broken down into eight, key powers that directly affect the decisions of war: the strength of the personnel, the air force, the army, the marines, logistics, natural resources, finances, and geographic strength. ${ }^{22}$ From the perspective of these eight aspects, the question can be asked, how is the Philippine military power in general?

The Armed Forces of the Philippines (AFP) or in Tagalog language, Sandatahang Lakas ng Pilipinas, is the official name of the Philippine military. AFP consists of the army, the navy, and the air force. Based on data from the Global Fire Power - a trusted site in military studies - in 2017, the Philippines military is ranked $50^{\text {th }}$ in the world from 133 countries. While in the Southeast Asia region, the position of Philippines military is under Indonesia (ranked 14), Vietnam (ranked 16), Thailand (ranked 20), and Malaysia (ranked 33). But the Philippines position is still above Singapore (ranked 65) which, in fact, has the most sophisticated weapons in Southeast Asia. However, if viewed from the sophistication of the main armaments system and the capabilities of its personnel, the Philippine military has lagged far behind the countries mentioned above. Even the Philippines is still ranked below Myanmar. So, the international community is not surprised when the Philippines finds it very difficult to overcome separatism and terrorism in their territories.

The Philippines military has been the target of criticism and pessimism by military observers. Especially the air force, as it is very limited in the number of fighter and navy aircrafts. The air force is also limited in the number of combat ships. Like most Southeast Asian countries, naval and air force development in the Philippine military is also under the shadow of the army. ${ }^{23}$ But, the condition is now gradually beginning to overcome this in balance with the arrival of advanced training aircraft semi fighters which were purchased from South Korea. Although it is not a real fighter aircraft, the purchase is certainly better than the previous conditions and was greeted with joy by air force personnel. As for maritime reinforcement, two frigates ex United States Coast Guard and two Strategic Sealift Vessel type ship from PT PAL Indonesia were bought and are claimed as the most advanced ship they have today. But, what happened after the reinforcement was not as expected and has not been able to change the international stigma of their military?

The Philippine military weakness can be seen from their action in the battle against terrorists on the Mindanao Island. Currently, fierce fighting is still taking

22 Global Fire Power, 2017 Philippines Military Strength: Current Military Capabilities and Available Firepower for the Nation of the Philippines, online: http://www.globalfirepower.com/country-military-strength-detail.asp?country_id=philippines, (July 17, 2017).

23 Gregory Vincent Raymond, "Naval Modernization in Southeast Asia: Under the Shadow of Army Dominance?", Contemporary Southeast Asia Vol. 39 No. 1, (2017). 
place between the Maute terrorist group and the Philippine army in the town of Marawi. A total of 180,000 residents, or about 90 percent of Marawi's total population, has left the city. Geographically, this city is located in the lush tropical hills, but, in recent months, it has turned into an urban battlefield. Phillipene President Duterte declared a state of martial law in Mindanao as troops outside Marawi approached the Isnilon Hapilon territory that had proclaimed himself as Southeast Asian "Emir" last year after declaring loyalty to ISIS. Mindanao has long been the headquarters of extremist movements in the Philippines. However, now the conditions are more complicated as extremists from Malaysia, Indonesia, and other countries in the Middle East have gathered in Mindanao. This sparked fears that such a situation could lead Mindanao to become a regional bastion of ISIS.

In the battle of Marawi, the Philippine military is overwhelmed and has difficulties facing extremists. They often make mistakes and unnecessary casualties occur in the Philippine military. The Philippine government and military were deeply tarnished when ISIS successfully defeated a Filipino mechanical infantry battalion. This is known from the circulation of a photograph where two armored personnel carriers (APC) were forced to be abandoned by Philippine troops on Saturday, May 27, 2017. The two APCs did not move after being tricked by Maute. They were cornered, immobilized, and lured to a landmine-filled spot. In fact, this strategy was not quite right because the use of an APC in urban warfare without escort from infantry caused these two APCs to be levy of Maute militias who attacked with anti-tank guns and heavy machine guns. This was not the first time there was an attack, during the initial phase of the APCs. This is because the Maute was able to seize armored vehicles belonging to the Philippine anti-terror police.

Facing difficulties on the ground, the Philippine military began to use air strikes. But, apparently, various difficulties and mistakes were still often befalling them. For example, there was a mistake that occurred on Wednesday May 31, 2017. The light military aircraft Marchetti S-211 accidentally fell to friendly fire. ${ }^{24}$ As a result, eight Philippine soldiers were wounded, and eleven soldiers were killed on the battlefield. After this incident, Manila decided to suspend the attack from the air temporarily. Indeed, the use of air strikes in the battle of the city was very risky. Then, on July 12, 2017, two new FA-50 fighter planes were on a mission to destroy the position of the Maute group in Marawi City when one of its bombs missed its target by 250 meters. The bomb blew up a nearby building and threw Filipino soldiers inside the shelter, killing two soldiers and wounding eleven others. The cause of the missed bomb is still being investigated by the Philippines. Possible reasons for the missed bomb were because of the complexity of the

24 Al-Jazeera, Philippines: 11 Soldiers Killed in Misdirected Air Raid, online: http://www.aljazeera.com/news/2017/06/philippines-10-soldiers-killed-friendly-fire170601031851380.html, (July 18, 2017). 
Transnational Islam, Regional Terrorism, and Military Power: The Rise of Muslim Special Unit in the Philippines Armed Force

battlefield, the fog disturbed the pilot's view, or it was the fault of the pilot', his fighter, or the bomb.

If examined further, the story of the Philippine military's failure to carry out its mission is not just about fighting terrorists in Marawi alone. It also happened during the liberation of hostages abducted by the Abu Sayyaf in 2016. On April 9, 2016, it was reported that 18 Filipino soldiers were killed, and 59 others were wounded in a battle. The surprise of the Abu Sayyaf stronghold reported only four militants were killed. The death toll suffered more from the Philippine army, as was accused by local officials; the Abu Sayyaf mobilized around 100 to 150 militants quickly. These results were more painful because those who died were mostly members of the Special Forces. The Philippine Army Special Forces were incorporated in the $44^{\text {th }}$ infantry battalion, $14^{\text {th }}$ infantry troops, and especially the $4^{\text {th }}$ Special Forces battalion. Based on information from various sources, the $4^{\text {th }}$ Special Forces battalion is known to be more active in counter-terrorism operations domestically, especially in the rebel areas of the Southern Philippines. Some of the tasks this troop carried out were anti-guerrilla operations serving the MILF and the MNLF, as well as the security operations of the Abu Sayyaf, Jamaah Islamiyah, and Al-Qaeda groups in Mindanao.

The international public must continue to appreciate the efforts of the Philippines government and military in making the situation peaceful again, especailly regarding the number of the Philippines soldier who died in the battlefield. However, as a sovereign state with a defensive component, what happens in Marawi certainly sparks questions from various parties regarding the performance of the Philippine government, particularly the Philippnes military. For months, Maute has taken control of the Marawi and, to this day, the city has not been fully recaptured by the Philippine military. The question could be asked, how could thousands of troops from dozens of battalions deployed, including with fighter aircraft, still be unable to destroy the insurgent forces that number only 400-500 people? At first, the Philippine military always refused help from foreign militaries. This is understandable because, of course, they want to maintain prestige and do not want to look weak from a regional and international view. Now, the United States Special Forces reportedly began to engage in operations against the Maute group. ${ }^{25}$ Nevertheless, the Philippine Military says that United States soldiers only provide technical assistance to end the siege in the Marawi town and not directly involved in the fighting.

As a regional terrorist movement, the Maute militia groups certainly want to expand their presence beyond the Philippines. Especially with the never-ending armed conflict in Marawi, the possibility of crossing the militias out of the Philippines is quite open. This situtation certainly makes the neighboring countries also wary. For example, Indonesia continues to tighten patrol in the area of

25 British Broadcasting Corporation - BBC, Marawi Siege: US Special Forces Aiding Philippine Army,online: http://www.bbc.com/news/world-asia-40231605, (July 18, 2017). 
Sangihe Archipelago which is directly adjacent to the Philippines. It could be understood the Indonesia has become more alert because, of course, Indonesia does not want to be missed in preventing extremist infiltration. ${ }^{26}$ From this exposure, it can be concluded that the Philippine military forces currently have not been able to achieve their ideal plan. So, to overcome separatists, extremists, and terrorists, the Philippine government needs to create alternative approaches, other than military. For example, these approaches can be done through religion and culture.

\section{MUSLIM SPECIAL UNIT: OPPORTUNITY AND CHALLENGE}

This section is the culmination of the analysis in this study, in which the Philippine government is attempting an alternative approach. This approach was implemented after conventional military action faced severe challenges. In April 2017, the Philippine Military announced plans to form a special combat unit of Muslim soldiers with quotas designated for Muslims in the Philippines. In more detail, the Philippine Air Force has a 600 quota for enlisted personnel and 80 for military officers. The Philippine Navy has 1,660 registered personnel and 140 for officers. With this new recruitment system, it is expected that AFP can form a battalion of Muslim soldiers. In the long term, a brigade or division of Muslims will be formed. Then, there is the prospect of the existence of Muslim special unit within the Philippines military. In some ways, the emergence of this special Muslim unit has a positive impact.

First, religious and cultural approaches can open up a larger dialogue space than in conventional military approaches. There are many factors, influencing the difficulty of the Philippine army extinguishing the conflict in the south. One of these factors is the less-welcomed cooperation by the MILF which has been granted special autonomy in two provinces. With the presence of a Muslim special unit, it is expected that the approach of the Philippine army to the MILF could be better because it would be done with a religious and cultural approach. As expressed by the Philippine government, the unit is expected to increase government efforts in the face of Islamic extremist rebel groups in the Philippines, particularly in the southerm region. ${ }^{27}$ The Muslim troops will be made up of the best units and can spread easily across the Muslim community as they can follow the culture and possess Islamic religious knowledge. As fellow Muslims, the army will be more aware of sensitive matters in their religion and culture.

Second, the special Muslim unit can facilitate adaptation and gain local community support. With this new order, the five percent quota for all enlistments

26 Sriwani Adolong, "Melihat Aktivitas Perbatasan Indonesia-Filipina di Tengah Krisis Marawi: Lebih Waspada Kalau Ada Warga Asing Masuk", Jawa Pos, (Sunday, June 4, 2017), p. 1.

27 Agence France Presse, Philippine Army Plans All-Muslim Units, online: http://www.thehindu.com/news/international/philippine-army-plans-all-muslimunits/article18061477.ece, (July 20, 2017). 
Transnational Islam, Regional Terrorism, and Military Power: The Rise of Muslim Special Unit in the Philippines Armed Force

in the Philippine Military will be allocated to Muslim applicants. The final goal of establishing this special unit is to establish a brigade or division dedicated to deployment to the troubled southern region of the Philippines. Later, the units will be placed in Muslim-majority areas. Since the approach to local communities is done by religious and cultural methods, through the presence of the brigades, the Philippine army is expected to operate in Muslim-majority areas without being viewed with suspicion by the local population. ${ }^{28}$ It is true that most Muslims in the southern Philippines see the deployment of nearly 100 percent of the army especially non-Muslims - within their communities as invading or imperialist forces. Therefore, it takes a special unit of the Muslim army to convince local residents that the mission of the military is to bring security to all Filipinos and not to oppress the Muslims in the south.

Third, the unit will facilitate better coordination and a more cooperative network between the militaries of Indonesia, Malaysia, and Brunei Darussalam, as they are neighboring countries with a Muslim majority population. As discussed above, the southern region of Mindanao, which is home to the Muslim minority of the Philippines, has been plagued by insurgency and separatism since 1970. This caused the loss of more than 120,000 lives. Although the large insurgent organizations have agreed on a ceasefire with the government for years, small factions and fractions still refuse to compromise and some even declared loyalty to the ISIS terrorist group. As has also been widely discussed above, that small group who affiliated with ISIS often hijacks vessels and kidnapping its crew that cross the state border waters, so this problem becomes a regional issue.

Therefore, coordination with the military of neighboring countries, such as Indonesia, Malaysia, and Brunei Darussalam, is absolutely necessary. The emergence of a special Muslim unit will at least reduce the partition between the Philippines and the other three Muslim-majority countries. Even in Malaysia and Brunei Darussalam, Islam is the official religion. So, the religious and cultural approach in both countries will be affected by the acceptance of both countries. This is although the military of each country must be professional in upholding sovereignty and humanity. Thus, the emergence of a Muslim special unit in the Philippine military opens up new opportunities for conflict resolution.

On the other hand, the emergence of a Muslim special unit in the Philippine military can also have negative impacts. First, there is the potential for factions within the military or a gap between Muslim units and other units. There have been many cases in various countries showing the breakdown of the military into competing and hostile factions. The most recent example was in July 2016 in Turkey; a military faction claimed to take over the administration of President Recep Tayip Erdogan. It was further reported that an F-16 Fighting Falcon fighter

28 Gracel Ortega, AFP Looking to Establish Battalion-Size Muslim Soldiers, Then Develop Into Brigade Division, online: https://www.update.ph/2017/04/afp-looking-to-establish-battalion-sizemuslim-soldiers-then-develop-into-brigade-division/16806, (July 20, 2017). 
jet owned by Turkish military, who was an Erdogan loyalist, was shot down by a military helicopter used by factions who supported the coup. In this case, it is clear that the split from within the Turkish military occured and harmed the legitimate government. Another example is the outbreak of the Myanmar military into two factions. The split stems from the rivalry of two factions led by Khin Nyunt, based on military intelligence, against Maung Aye, with a background of combat and psychological warfare. Both continue to clash to expand their influence and power in Myanmar. ${ }^{29}$ Based on these examples of experience, if taken in the context of the Philippines Military, if not properly managed, not treated fairly, and not instilled in the proper spirit of nationalism, then the emergence of a special Muslim unit can be a new problem for the Philippines. Instead of easing the process of realizing peace in the Muslim-majority South, it could become a new "fuel" in fueling the already existing conflict.

Secondly, a special unit can increase the stigma that Muslims are terrorists, so therefore must be fought with hardcore Muslims. Islam is often accused of being a religion or belief that is full of violence and hard ideology. Indeed, in Islam there is familiarity with the existence of Jihad, which means fighting in the way of Allah, but this meaning is often mistaken as an act that does not have the concept of human rights. In general, these misconceptions are manifested as the idea that fighting for religion is a duty and, to realize it, killing is considered valid and permissible. This assumption makes Islam often associated with the extremist and terrorist movement; whereas, in fact, it is actually an issue that is only deliberately linked to Islam. The issue is used to destroy the name of Islam by constructing the image of a radical and violent religion that does not value democracy and other freedoms. That understanding creates Islamaphobia. In the life of society, Islamaphobia is manifested by fear and hatred towards Islam and all Muslims. The fear and hatred also refer to the practice of discrimination against Muslims by marginalizing them from economic, social, political, and cultural life. ${ }^{30}$ As a result, the people of the world are not the least affected by the issue. These reasons are why the emergence of a Muslim special unit in the Philippine military, if not properly managed, may strengthen this Islamaphobic stigma. It may appear as if it is necessary to fight radical Muslims with other Muslims who are not less radical in military gear.

\section{CONCLUSION}

As a sovereign state with a defense component, the Philippine military forces currently are not in the ideal condition for maintaining security in the country.

29 Ita Mutiara Dewi, "Pengalaman Militer Burma: Sebuah Analisis Historis-Politis", Istoria: Jurnal Pendidikan dan Ilmu Sejarah Vol. 1 No. 1, (2005), p. 14.

30 Bayu Mitra A. Kusuma, "Mereduksi Islamofobia Melalui Aksi Nyata Lintas Iman: Sebuah Kritik Sosial”, in Keberpihakan dan Kepedulian Lintas Iman Untuk Difabel, ed. Bayu Mitra A. Kusuma and Zaen Musyirifin, (Yogyakarta: Interfidei, 2016), p. 188. 
Transnational Islam, Regional Terrorism, and Military Power: The Rise of Muslim Special Unit in the Philippines Armed Force

This is evidenced by the difficulties and problems they face in terrorism cases. These terrorist cases include incidents such as ship hijacking with the abduction of its crew by the Abu Sayyaf group in the border waters and direct gunfire in Marawi city combat against Maute group who is affiliated with ISIS, or Daesh. The Philippine military has always refused aid from foreign military because they want to maintain prestige and do not want to look weak in the international worldview. Therefore, a breakthrough appeared needed to aid in the anticipation of the conditions of their military strength that are not ideal. This means that conventional military approaches were not enough, therefore there was a need for alternative approaches, such as religion and culture. Therefore, the Philippine military formed a Muslim special unit.

The establishment of a Muslim special unit within the Philippine military has a good chance of being successful, but there are also big challenges. The opportunities for success include a larger dialogue space than in conventional military approaches due to a more religious and cultural approach. Also, the unit has the ability to facilitate adaptation and gain local community support. Third, there is the opportunity to facilitate the coordination and cooperation of a network with the Indonesian, Malaysian and Brunei Darussalam militaries, as they are neighboring countries with a majority Muslim population. This network would be especially useful in dealing with piracy actions against ships passing through the border waters. But, the emergence of these opportunities is followed by risky challenges. First, there is the potential for factions within the military or gap between Muslim units and other units. Second, the military unit can increase the stigma that Muslims are terrorists and must also be fought with hardcore Muslims.

\section{BIBLIOGRAPHY}

Adolong, Sriwani, "Melihat Aktivitas Perbatasan Indonesia-Filipina di Tengah Krisis Marawi: Lebih Waspada Kalau Ada Warga Asing Masuk", Jawa Pos, (Sunday, June 4, 2017).

Affandi, Hakimul Ikhwan, Akar Konflik Sepanjang Zaman: Elaborasi Pemikiran Ibn Khaldun, (Yogyakarta: Pustaka Pelajar, 2004).

Agence France Presse, Philippine Army Plans All-Muslim Units, online: http://www.thehindu.com/news/international/philippine-army-plans-all-muslimunits/article18061477.ece, (July 20, 2017).

Al-Jazeera, Philippines: 11 Soldiers Killed in Misdirected Air Raid, online: http://www.aljazeera.com/news/2017/06/philippines-10-soldiers-killed-friendlyfire-170601031851380.html, (July 18, 2017). 
Alexander, Yonah, "Contemporary Terrorism: From National to Regional and Global Threats", Defence Against Terrorism Review Vol. 1 No. 2, (2008).

Baviera, Aileen and Jay Batongbacal, The West Philippine Sea: The Territorial and Maritime Jurisdiction Disputes from a Filipino Perspective, (Manila: The Asian Center and Institute for Maritime Affairs and Law of the Sea University of the Philippines, 2013).

Bell, Christine and Vanessa Utley, "Chronology of Mindanao Peace Agreements", The Political Settlements Research Programme Briefing Paper Vol. 2, (2015).

British Broadcasting Corporation - BBC, Marawi Siege: US Special Forces Aiding Philippine Army, online: http://www.bbc.com/news/world-asia-40231605, (July 18, 2017).

Brunet-Jailly, Emmanuel, "The State of Borders and Borderlands Studies 2009: A Historical View and a View from the Journal of Borderlands Studies", Eurasia Border Review Vol. 1 No. 1, (2009).

Chapman, Bert, "China's Nine-Dashed Map: Continuing Maritime Source of Geopolitical Tension”, Geopolitics, History, and International Relations Vol. 8 No. 1, (2016).

Dewi, Ita Mutiara, "Pengalaman Militer Burma: Sebuah Analisis Historis-Politis", Istoria: Jurnal Pendidikan dan Ilmu Sejarah Vol. 1 No. 1, (2005).

Emmers, Ralf, "ASEAN and the Securitization of Transnational Crime in Southeast Asia", The Pacific Review Vol. 16 No. 3, (2003).

Global Fire Power, 2017 Philippines Military Strength: Current Military Capabilities and Available Firepower for the Nation of Philippines, online: http://www.globalfirepower.com/country-military-strengthdetail.asp?country_id=philippines, (July 17, 2017).

Gowing, Peter G., "Moros and Khaek: The Position of Muslim Minorities in the Philippines and Thailand", in Reading on Islam in Southeast Asia, ed. Ahmad Ibrahim et al., (Singapore: Institute of Southeast Asian Studies ISEAS, 1985).

Hashim, Ahmed S., The Impact of the Islamic State in Asia: Policy Report, (Singapore: S. Rajaratnam School of International Studies - RSIS NTU, 2015).

Jones, Sidney, "Pro-ISIS Groups in Mindanao and Their Links to Indonesia and Malaysia", Institute for Policy Analysis of Conflict (IPAC) Report Vol. 33, (2016). 
Transnational Islam, Regional Terrorism, and Military Power: The Rise of Muslim Special Unit in the Philippines Armed Force

Kusuma, Bayu Mitra A., Abu Sayyaf Piracy: An ASEAN Political Security Challenge, online: http://isais.or.id/en/abu-sayyaf-piracy-an-asean-politicalsecurity-challenge, (July 4, 2017).

Kusuma, Bayu Mitra A., "Islam, Asymmetric Policy, and Social Conflicts: The State's Role as a Root of Radicalism in the Philippines and Thailand", IKAT: The Indonesian Journal of Southeast Asian Studies Vol. 1 No. 1, (2017).

Kusuma, Bayu Mitra A., "Mengelola Perbatasan dengan Border Governance", Jawa Pos Radar Banyuwangi, (Saturday, April 16, 2016).

Kusuma, Bayu Mitra A., "Mereduksi Islamofobia Melalui Aksi Nyata Lintas Iman: Sebuah Kritik Sosial", in Keberpihakan dan Kepedulian Lintas Iman Untuk Difabel, ed. Bayu Mitra A. Kusuma and Zaen Musyirifin, (Yogyakarta: Interfidei, 2016).

Laqueur, Walter, The New Terrorism: Fanaticism and the Arms of Mass Destruction, (New York: Oxford University Press, 1999).

Nugroho, Irwan, Investigasi: Menelusuri Mata-Mata Abu Sayyaf, online: https://x.detik.com/detail/investigasi/20161013/Menelusuri-Mata- mata-AbuSayyaf/index.php, (July 13, 2017).

Ortega, Gracel, AFP Looking to Establish Battalion-Size Muslim Soldiers, Then Develop into Brigade Division, online: https://www.update.ph/2017/04/afplooking-to-establish-battalion-size-muslim-soldiers-then-develop-into-brigadedivision/16806, (July 20, 2017).

Raymond, Gregory Vincent, "Naval Modernization in Southeast Asia: Under the Shadow of Army Dominance?", Contemporary Southeast Asia Vol. 39 No. 1, (2017).

Rustandi, Agus, The Impact of China's 'Nine-Dash Line' Claim on ASEAN's Role in the Indo-Pacific Region, (Canberra: The Centre for Defence and Strategic Studies (CDSS) Australian Defence College, 2015).

Sanak, Yohannes, Human Security dan Politik Perbatasan, (Yogyakarta: PolGov UGM, 2014).

Snyder, Craig A., Contemporary Security and Strategy, (New York: Palgrave Macmillan, 2008).

Tan, Andrew, Force Modernisation Trends in Southeast Asia, (Singapore: Institute of Defence and Strategic Studies - IDSS NTU, 2004). 
United States Institute of Peace, "Teaching Guide on International Terrorism: Definitions, Causes, and Responses”, Education Program Vol. 202, (2001).

Van Houtum, Henk, "The Geopolitics of Borders and Boundaries", Geopolitics Vol. 10, (2005).

Bayu Mitra A. Kusuma has been a lecturer at the Faculty of Da'wah and Communication since 2015 and researcher at the Institute of Southeast Asian Islam (ISAIs) since 2016, both in the Sunan Kalijaga State Islamic University (UIN) Yogyakarta, Indonesia. He is currently also trusted as a project officer for the Australia-Indonesia Partnership for Justice (AIPJ) 2 program which is managed by the Kalijaga Institute for Justice (KIJ) UIN Sunan Kalijaga. He achieved Bachelor of Public Administration (S.AP) from the Faculty of Administrative Science, Universitas Brawijaya, Malang and obtained his first Master's degree (M.AP) from the Graduate School of Public Administration in the same university. Then completed his second Master's degree in Political Science (M.Pol.Sc) of Security Studies from the Faculty of Political Science and Law, Burapha University, Thailand. 